\title{
Nütrisyonel Hastalıkların Deri Bulguları
}

\section{Cutaneous Manifestations Of Nutritional Disease}

\author{
Erdinç Terzi ${ }^{1}$, Aynur Akyol ${ }^{2}$
}

1 Dermatoloji Kliniği, Özel Sakarya Vatan Hastanesi,Sakarya;

2 Dermatoloji Ana Bilim Dalı, Ankara Üniversitesi Tıp Fakültesi,Ankara, Türkiye

öz

Nutrisyonel hastalıklar, besin alımının eksikliği veya daha az sıklıkla aşırı besin alımı nedeniyle gelişmektedir. Nutrisyonel eksiklikler yetersiz alım,bozulmuş emilim, spesifik besinlerin metabolizmasındaki bozukluklar veya uygun olmayan yararlanma sonucunda ortaya çıkmaktadır. Nutrisyonel hastalıkların deri bulguları Skorbüt ve Pellegrada olduğu gibi çok spesifik olabilir.Ancak deri bulguları sıklıkla tanı koydurucu değildir.

Anahtar Kelimeler: Nutrisyonel Hastalıklar, Deri Bulguları

\section{ABSTRACT}

Nutritional disease is caused by nutrient deficiency or, less commonly, by nutrient excess. Nutritional deficiency results from inadequate intake, impared absorbtion, defective metabolism of specific nutrients, or improper utilization.Cutaneous findings in nutritional disease can be very specific such as scurvy, pellegra. However the skin findings are often nondiagnostic..

Keywords: Nutritional disease, cutaneous, manifestation

Başvuru Tarihi/Received: $\quad$ 02-07-2016

Kabul Tarihi/Accepted: $\quad$ 11-09-2016 
THE CUTANEOUS MANIFESTATIONS OF NUTRITIONAL DISEASE

Due to lack of nutrient intake, malabsorption and acceleration of intestinal passage as in diarrhea,deficiency of essential nutrient elements can be developed. Isolated deficiencies can also develop as well as combined protein,vitamin and mineral deficiencies. Increased metabolic needs and parenteral nutrition may cause malnutrition ${ }^{1}$.

\section{PROTEIN ENERGY MALNUTRITION}

Protein energy malnutrition leads to spectrum of disorders from marasmus to kwashiorkor. Marasmus is a serious protein and calorie intake deficiency. It is characterized by the loss of less than $60 \%$ of body weight and lack of peripheral edema ${ }^{2,3}$. Marasmus is more frequent than kwashiorkor. It is seen in third world due to the food shortage whereas it emerges in western countries in serious diseases and in patients hospitalized in intensive care $^{2,3,4,5}$.Phisical signs of protein energy malnutirion is summarized in table 1.

In marasmus, the skin appears dry,loose, and wrinled. Loss of the buccal adipose tissue results in the characteristic monkey face appearance.Follicular hyperkeratosis is distinctive in adults. Hair becomes thin,sparse and slow growing.Sometimes lanuga hairs appear especially in face and neck.Fissures can occur in finger nails $2,3,4,5$.

Kwashiorkor is characterized by severe protein malnutrition and relative increase in carbonhyrate $^{2}$. It is marked by loss of $60 \%$ to $80 \%$ of body weight and peripheral edema. In children, mental retardation and development retardation of skeleton, muscular atrophy, fatty infiltration of the liver occurs ${ }^{2,3,4,5}$.
Cutaneous findings of kwashiorkor is more visible in dark-skinned individuals. Desquamation and hypopigmented lesions in perioral and edematous parts of skin may appear.On knees,elbows,ankles and intertriginous areas, there are sharply defined hyperpigmented macular lesions.Fissures appear in flexural areas depending on intensive desquamation. Hypopigmentation appears in hairs. The number of hair follicles in telogen phase increases and length of hair follicles in anagen phase decreases. Mucosal lesions such as cheliosis,xerophthalmia,vulvovaginitis can be developed. In kwashiorkor patients, ulcerations in skin can be seen depending on zinc deficiency. In kwashiorkor, anorexia,apathy, irritability, hypoalbuminemia and immunodepression may occur ${ }^{2,3,4,5}$.

In addition to a diet rich in animal protein,vitamin and mineral supplement should be provided in treatment ${ }^{2,3}$.

\section{MINERAL DEFICIENCIES}

The phisical signs of mineralş deficiencies is shown in table 2.

\section{IRON DEFICIENCY}

In iron deficiency, general symptoms such as fatique,tachycardia, atrophy of the filiform papilla in tongue, perleche,disphalgia,koilonychia are seen.Generalized pruritus and hair loss can be seen.Iron deficiency is diagnosed by clinical findings and low serum iron levels.Iron preparates are used in treatment ${ }^{2}$.

\section{SULFUR METABOLISM}

Sulfur is the main component of chondroitin sulphate which provides dermal collagen formation and keratinization ${ }^{2,6}$.Although keratin production 
seems normal, growth rate decreases in hair and nails as a result of deficient intake of aminoacides containing sulfur.Trichothiodystrophy is an autosomal reccessive sulfur metabolism disease and seen in association with ectodermal dysplasia. It appears with the loss of $50 \%$ of sulfur and sistein in hair ${ }^{2,3}$.

\section{METABOLISM OF COPPER}

Copper exists in the structure of superoxide dismutase enzyme in erythrocytes. Copper deficiency can occur in infants breastfeeding with low-copper including milk and malnutrated children fed with high calorie diet deficient in copper.Anemia,neutropenia and growth retardation appears ${ }^{2}$.

\section{MENKES' DISEASE}

It is transmitted as an X-linked reccessive trait.There is a defect in copper absorption.Serum copper and ceruloplasmin levels are low in patients. Elastin production is corrupted because of the disfunction of copper including enzyme lysyl oxidase. Growth retardation,cerebral degeneration,arterial lesions,weakened bones, brittle hair,hypopigmentation happen in Menkes' disease.It does not respond well to copper treatment and results in death.

\section{SELENIUM METABOLISM}

Selenium is an essential element which is in the structure of glutathione peroxidase enzyme. It has a crutial role against oxidative damage of endogenous peroxides.Dietary selenium comes from red meat,marine fishery, cereal,vegetables and milk. In America, it is informed that in prolonged parenteral nutrition taking patients it causes dyschromia, whitened nail beds and hypopigmented skin lesions ${ }^{3}$.

\section{ZINC METABOLISM}

Zinc is one of the essential elements.Zinc has important functions for normal growth, development, reproduction and immunity ${ }^{7}$. Zinc is involved in alcaline phosphatase, alcohol dehydrogenase and some digestive enzymes.It regulates DNA and RNA polymerase,timidin kinase and ribonucleas. Zinc deficiency is seen hereditary and acquired forms ${ }^{7}$.

\section{ACRODERMATITIS ENTEROPATHICA}

It is an autosomal recessive hereditary disorder which is clasically characterised by the triad acral dermatitis,alopecia and diarrhea ${ }^{8}$. It is rare,seen worldwide, has no sexual and racial predilection.

Acrodermatitis enteropathica appears due to inefficient absorption of zinc in diet.as absorbtion mechanism is not totally broken in acrodermatitis enteropathica, little amount of zinc absorbtion from diet can be provided.

Acrodermatitis enteropathica appears days or weeks after birth, as erytematous,scurfy,eczamatous plaques in face,scalp and anogenital regions.Lesions may become vesiculobullous, pustular and erosive.Perleche is an early seen symptom and it points to relapses.Superficial aphthous lesions may develop in oral mucosa.Annular lesions and brightly erytematous plaques accompanied by paronychia are seen in extremities. Secondary infections caused by bacteria and Candida albikans may aggravate dermatitis.Alopecia can be seen in scalp,eyelashes and eyebrows ${ }^{1,8}$.

Diarrhea is intermittent as well as being inconstant.If diarrhea is severe and persistent,it can cause fluid and electrolyte 
loss.In a few weeks, developmental retardation can appear.Emotional and mental alterations are frequent symptoms yet improve in 24-48 hours by zinc treatment ${ }^{8}$. If the case is not treated, hypogonadism happens in adolescence.Disfunction of zincdepending retinol binding protein causes photophobia.Anorexia, anemia and hyposemia occur.In mild cases,clinical symptoms are less severe due to high doses of zinc but developmental retardation, dwarfism, delayed puberty,hypogonadism, frequent infections, retarded wound healing and mental disorders can occur $^{6,8}$.Acrodermatitis enteropathica is typically fatal in infants but in small number of papers spontaneous remission is reported ${ }^{7,9}$.

Plasma or serum zinc levels are the best and favorite method for evaluation of zinc status.Normal plasma zinc level is 70-110 whereas serum zinc level is $80-120^{7,9}$.

When acrodermatitis enteropathica is not treated, it results in poor prognosis. There are cases reported became an adult without treatment.In order to prevent relapse of illness,long term treatment is necessary.In treatment,2-3 times 30-55mg elementary zinc per day is given depending on level of deficiency.Cases respond dramatically to treatment ${ }^{7,9}$.

\section{ACQUIRED ZINC DEFICIENCY}

Acquired zinc deficiency finding and symptoms are similar to those of acrodermatitis enteropathica.In several papers,acquired zinc deficiency is reported due to lack of zinc in breast-milk with classical clinical findings of acrodermatitis enteropathica ${ }^{10,11,12,13}$. In these cases, since zinc absorbtion is normal,good treatment response is indicated ${ }^{10,14}$.

In patients and infants that take long term-total parenteral nutrition due to inflammatory bowel disease and chronic diarrhea,acrodermatitis enteropathica-like skin lesions occur because of zinc deficiency ${ }^{2,15}$.

In early periods of acquired zinc deficiency, hair growth rate decreases, diffuse hair thinning occurs and weeks later total alopecia develops.As deficiency gets worse,structural changes in hair such as splitting hairs, transverse striation of hair fibers,pseudo monilethrix,longitudinal lines appear.In severe zinc deficiency, deep transverse lines in nails (Beau's lines) occurs due to malfunction of nail formation ${ }^{2,8}$.

Treatment in $2 \mathrm{mg} / \mathrm{kg} /$ per day oral zinc sulphate for adults.In severe deficiency, $0,2-0,3 \mathrm{mg} / \mathrm{kg} /$ per day parenteral zinc chloride will be sufficient.

\section{VITAMIN DEFICIENCIES}

Vitamins are biologically active components that are required for normal body functions. They function as coenzymes in enzyme systems of different metabolic pathways.Vitamins are classified as water soluble and fat soluble. The phisical manifestations of vitamin deficiencies is presented in table 3 .

\section{DEFICIENCY OF WATER SOLUBLE VITAMINS}

\section{VITAMIN B COMPLEX}

\section{THIAMINE DEFICIENCY}

Thiamine functions in carbonhydrate metabolism and enzyme systems such as pentose monophosphate pathway as cofactor.Thiamine takes part in decarboxylation of alpha-keto acids.It has an important role in developmental process and neurological functions.Thiamine deficiency is seen in pregnants, people eating polished 
rice, in lactation period, having ulcerative colitis,having cheliac disease,having achlorhydria and in chronic alcholics.Classical symptoms of thiamine deficiency are symmetrical progressive polyneuritis,edema,fatigue, intestinal obstruction and cardiac insufficiency.Mucocutaneous findings include edema and glossitis.In severe deficiency,Korsakoff's psychosis and Wernicke's encephalopathy may occur. Thiamine defficiency is diagnosed by clinical findings, increase of pyruvate in blood and decrease of renal excreation of thiamine ${ }^{1,2}$. In mild cases, treatment is $10-20 \mathrm{mg}$ thiamine per day given in three doses. In moderate neuropathy, 20-30nmg thiamine per day is given.In cardiac insuffiency, Korsakoff's psychosis and Wernicke's encephalopathy 50$100 \mathrm{mg}$ thiamine is given intramuscular or intravenous until clinical response to treatment ${ }^{1,2}$.

\section{RIBOFLAVIN DEFICIENCY}

Riboflavin fuctions as an essential coenzyme as flavin mononucleotide or flavin adenine dinucleotide in several oxidationreduction reactions in carbonhydrate metabolism ${ }^{1,2}$. Riboflavin deficiency is most common seen in chronic diarrhea, liver patients,chronic alcoholism, hypotroidism,postoperative parenteral nutrition and phototerapy treated neonatals because of neonatal hyperbilirubinemia ${ }^{1,16}$.

Riboflavin deficiency is called orooculo-genital syndrome.Perleche in lip corners,angular stomatitis,superficial fissures is seen.Seborrheic dermatitis-like erythematous scurfyy lesions can be seen in nasolabial sulcus, nose,ears, eyelids and genitals.Glossitis,corneal vascularization konjonctivit and intertsiel keratitis may occur.Three divided doses for two weeks with
5-15 $\mathrm{mg}$ of oral riboflavin is used in treatment ${ }^{1,2,16}$.

\section{NIACIN DEFICIENCY}

Niacin is converted to nicotinamide adenine dinucleotide and nicotinamide adenine dinucleotide phosphate.These coenzymes play an important role in fatty acid synthesis and electron transport in cell respiration in body.Niacin is synthesized from tryptophan-niacin pathway or from the diet.Daily requirement of niacin is $10-20$ milligrams.Niacin deficiencycalled Pellagra ${ }^{1}$.

Pellagra is defined in 1785 by Casal as a disease associated with indian corn in diet ${ }^{1}$. Today Pellagra is endemic in Africa and Asia.It may sporadically develop due to malabsorbtion in inadequate diet,alcoholism,liver cirrhosis,the elderly people,postoperative parenteral nutrition, and hereditary or acquired defect in tryptophanniacin pathway ${ }^{1,16,17}$. Rarely isoniazid,6mercaptopurine,5-fluorouracil can cause Pellagra-like symptoms $s^{1,2,17}$.

Carcinoid syndrome may cause Pellagra. It causes fatique,weight loss, diarrhea, abdominal pain,bronchial asthma, fibrosis of heart valves,itching,scleroderma-like skin thickening and Pellagra.These symptoms of the tumor tissue is due to the excessive secretion of seratonin,Pellagra occurs as a result of spending large amounts of seratonin for the synthesis of tryptophan.

In Hartnup disease,Pellagra-like skin lesions,cerebellar ataxia,increased levels of indican in the urine, aminoaciduria, and mental changes occur.Skin and central nervous system symptoms improve with nicotinamide treatment but nicotinamide does not correct the aminoaciduria and excessive excretion of indican. 
Clasically, Pellagra reveals with 3D(Diarrhea,Dermatitis,Dementia)

triad.Painful, erythematous macular lesions are seen in trauma areas and regions that are on the sun. Lesions are symmetrically positioned on the dorsal side of hands, forearms,face,neck and chest.Over time,sharply circumscribed, keratotic, hyperpigmented plaques develop. Lesions in the chest and neck causes the appearance Casal's Cravat. Malar rash on the face, erythematous, scurfy lesions in genital and perianal region can be seen. Keilosis, glossitis, angular stomatitis, painful fissure and ulcerations on mucous membranes occur.In addition to the findings of the skin,fatique, anorexia, diarrhea , amenorrhea, and neuropsychiatric changes are seen. Apathy, depression, pyschosis, coma, encephalopathy, peripheral and spinal cord involvement can be seen $^{1,2,16}$.

Table 1. Phisical signs of protein energy malnutrition

\begin{tabular}{|c|c|}
\hline $\begin{array}{l}\text { PROTEIN } \\
\text { ENERGY } \\
\text { MALNUTRITION }\end{array}$ & PHYSICAL SIGNS \\
\hline 1-Marasmus & $\begin{array}{l}\text { *The skin appears dry, loose, and wrinled. } \\
\text { * Monkey face appearance. } \\
\text { *Follicular hyperkeratosis is distinctive in } \\
\text { adults. } \\
\text { *Hair becomes thin,sparse and slow } \\
\text { growing. } \\
\text { *Lanuga hairs in face and neck. } \\
\text { *Fissures can occur in finger nails }\end{array}$ \\
\hline 2-Kwashiorkor & $\begin{array}{l}\text { *Perioral desquamation and } \\
\text { hypopigmentation *Hiperpigmented } \\
\text { macular on the knees, elbows, ankles and } \\
\text { intertriginous areas. } \\
\text { *Fissures and intensive desquamation in } \\
\text { flexural areas. } \\
\text { *Hypopigmentation appears in hairs. } \\
\text { *Mucosal lesions such as cheliosis, } \\
\text { xerophthalmia, vulvovaginitis. } \\
\text { *Skin ulcerations. } \\
\text { *Anorexia, apathy, irritability, } \\
\text { hypoalbuminemia and immunodepression } \\
\text { *Mental retardation, muscular atrophy, } \\
\text { fatty infiltration of the liver. }\end{array}$ \\
\hline
\end{tabular}

Treatment is given doses of $300-1000 \mathrm{mg}$ oral niasinamid.If oral therapy can not be done, $100-250 \mathrm{mg}$ can be applied to 2-3 times a day.

Table 2. Physical manifestations of mineral deficiency

\begin{tabular}{|c|c|}
\hline $\begin{array}{l}\text { MINERAL } \\
\text { DEFICIENCY }\end{array}$ & PHYSICAL \\
\hline Iron Deficiency & $\begin{array}{l}\text { *Fatique, tachycardia } \\
\text { *Atrophy of the filiform papilla in } \\
\text { tongue,perleche, disphalgia,koilonychia } \\
\text { * Generalized pruritus and hair loss }\end{array}$ \\
\hline $\begin{array}{l}\text { Copper } \\
\text { Deficiency }\end{array}$ & $\begin{array}{l}\text { *Anemia,neutropenia and growth } \\
\text { retardation } \\
\text { *Growth retardation,cerebral degeneration, } \\
\text { arterial lesions, weakened bones, brittle } \\
\text { hair,hypopigmentation are seen in Menkes } \\
\text { disease }\end{array}$ \\
\hline $\begin{array}{l}\text { Selenium } \\
\text { Deficiency }\end{array}$ & $\begin{array}{l}\text { * Dyschromia,whitened nail beds and } \\
\text { hypopigmentation }\end{array}$ \\
\hline Zinc Deficiency & \\
\hline $\begin{array}{l}\text { *Acrodermatitis } \\
\text { enteropathica }\end{array}$ & $\begin{array}{l}\text { *Eczamatous plaques in face,scalp and } \\
\text { anogenital regions } \\
\text { *Perlech,superficial aphthous lesions } \\
\text { *Alopecia,retarded wound healing } \\
\text { *Diarrhea,developmental retardation } \\
\text {,hypogonadism, delayed puberte, frequent } \\
\text { infection } \\
\text { *Anorexia,anemia,hyposemia,photophobia }\end{array}$ \\
\hline
\end{tabular}

\section{PYRIDOXINE DEFICIENCY}

Pyridoxine is a pyridine derivative and it serves as a coenzyme in decarboxilation and transamination or amino acids,tryptophan conversion of niasine and metabolism of essential fatty acids. ${ }^{1,2}$

Pyridoxine deficiency may develop in alcoholics, as a result of use of drugs such as isoniaside,hydralasine, penicillamine and use of deoxypyridine which is pyrdoxine antagonist.In addition, despite to the change in 
the metabolism of pyridoxine in women use oral contraceptives,symptoms occur in very few of them due to pyridoxine deficiency ${ }^{1}$.

Seborrheic dermatitis-like lesions, keilosis, glossitis, peripheral neuropathy, lymphopenia, allodynia,anemia may occur.Convulsions may occur in infants. Anorexia, nausea, vomiting and rarely erythema,scurfiness and hyperpigmentation in the dorsal side of the arms and legs occurs.Diagnosis is placed on decreased level of blood pyridoxine levels and obtaining a good response to treatment in a week $^{1,2}$.

50-100 mg/per day dose of oral pyridoxine is used in the treatment.Acquired epidermolysis bullosa like vesicular dermatitis and peripheral sensory neuropathy have been reported in two patients taking high-dose pyridoxine $^{18}$.

\section{BIOTIN DEFICIENCY}

It is a cofactor of the carboxilase enzyme that serves in carbonhydrates, fat and protein metabolisms. It is common in animal and plant products, however, is found in small amounts.Best sources are liver,egg yolks and grains.In addition, people can benefit from biotin that is made by bowel bacteria ${ }^{19}$.

Biotin deficiency may be acquired and genetic.Acquired biotin deficiency occurs rarely due to biotin in foods is common and bacterial biotin syntehesis in intestines.(19) Usually, acquired deficiency develops by eating the raw egg whites.This is because the avidin contained in egg whites are breaking biotine absorbtion in intestine by binding biotin.(19) Acquired biotin deficiency may develop after short bowel syndrome,parenteral nutrition and broad spectrum antibiotic use ${ }^{20}$.

There are two forms of hereditary biotin deficiency as neonatal and infantil.Both are autosomal recessive.Neonatal biotin deficiency occurs due to the lack of holocarboxylase synthetase enzymes and manifestation usually occurs in the first 6 weeks of life.Infantil biotin dificiency occurs due to lack of the enzyme biotidinase and manifestation often occurs after the first three months of life ${ }^{21}$.

In acquired biotin deficiency,xerosis,generalized

pallor,periorificial dermatitis and alopecia are seen.Desquamation may be seen especially in the extremities and tongue is atrophic.In acquired biotin deficiency, anorexia, irritability, depression,myalgia,

hyperesthesia and hypotonia can be observed $^{1,2}$.

In acquired biotin deficiency when 150 ug/per day biotin is given,symptoms regress within a week.Urinary organic acid excretion is diagnostic for holocarboxylase and biotidinase deficiency.In holocarboxylase deficiency, with $10-40 \mathrm{mg} /$ per day biotin treatment symptoms in all patients will completely improve.Development of the clinical manifestation can be prevented by prenatal diagnosis and treatment.In biotinidase deficiency,serum biotidinase levels are low.It is treated by $5-10 \mathrm{mg} /$ per day biotin. However, optical and vestibulococlear nerve damage may be permanent.

\section{FOLIC ACID DEFICIENCY}

Folic acid is found in liver,meat and meat products,green vegetables and milk.In organisms, it is converted into folinic acid,that is biologically active form.In this transformation,there is a need for vitamin C.Folinic acid is in charge of a carbon unit transfer, the production of red blood cell and growth.Deficiency is seen in pregnant and 
lactating women, in chronic alcoholics.In deficiency, anticonvulsant anemia, diffuse hyperpigmentation,glossitis, keilitis, apthous lesions in oral mucosa are seen ${ }^{1,2}$. Diagnosis is made by the reduce of serum and erytrocyte folic acid levels.Treatment is daily 1-3 tablets of 5 milligram of folic acid tablets ${ }^{1,2}$.

\section{VITAMIN B12}

Vitamin B12 is involved in nucleic acid synthesis and in red blood cell production. Vitamin B12 absorbed from distal ileum after it is connected in acidic environment to intrinsic factor,which is synthesizes in the stomach. Vitamin B12 deficiency occurs due to reduction of synthesis of intrinsic factor in stomach and after postgastrectomy, reduction of absorbtion due to excessive bacterial growth after infection diphyllobothrium latum,reduction of ileal absorption(tropical sprue, regional enteritis, tuberculosis, Whipple's disease, post ileectomy status,Zollinger-Ellison syndrome).Because of the presence of large stores of cyanocobalamin in the body and daily needs are the minimal level, 3-6 years are necessary for the deveopment of vitamin B12 deficiency.Megaloblastic anemia develops due to folic acid metabolism changes.Although cutaneous findings are rare,generalized hyperpigmentation,macular pigmented lesions on oral mucosa,glossitis and poliosis are seen ${ }^{22,23}$.

In treatment,initially $1 \mathrm{mg} /$ week parenteral cyanocobalamine for 1 month,then $1 \mathrm{mg} /$ month parenteral cyanocobalamin for 6 months are given.

\section{VITAMIN C DEFICIENCY(SCURVY)}

Vitamin C essential for collagen production.Connective tissue is important for osteiod tissue,for ensuring continuity of mesenchymal tissues such as tooth dentin layer and for wound healing.Ascorbic acid is the coenzyme of proline hydroxylase, which is an important enzyme in the syntesis of collagen $^{24}$.

Daily requirement of ascorbic acid is $30-80$ $\mathrm{mg}$. In ascorbic acid deficiency, the amount of intracellular protocollagen residues increases because of insufficient hydroxylation of proline and very small amounts of triple helix structure are secreted. The excessive increase in intracellular protocollagen molecules reduce type 1 and type 2 collagen syntesis ${ }^{25}$.Scurvy occurs often in elderly and in alcoholics because of inadequate fruit and vegetable intake.Need for vitamin C increases in pregnancy, lactation,thyrotoxicosis, acute and chronic infections,operations and burns.Clinical findings develop depending on the deterioration of collagen syntesis. Follicular hyperkeratosis, perifollicular hemorrhages, gingival hypertrophy,erosions and hemorrhages in the body cavity are seen. Edema,hyperplasia,spontaneous bleeding is seen in the gums.Subungual,subcutaneous, intramuscular, $\mathrm{i}$ ntraarticular and subperiostal hemorrhages can be seen.Fatigue,weight loss,depression,edema of joints, artralgia,epistaxis and diarrhea may occur.Vitamin C deficiency delays wound healing ${ }^{1,2,26,27}$.

It is diagnosed by the reduction of serum ascorbic acid levels and clinical findings.For treatment $1000 \mathrm{mg} /$ day in four divided doses should be applied until the clinical findings improved.Then treatment is continued with 100-300 mg/day.

DEFICIENCY OF FAT SOLUBLE VITAMINS

VITAMIN A DEFICIENCY

Vitamin $A$ is essential for 
growth,development and normal functions of skin,eyes and gonads.Daily vitamin A requirement is 5000 IU.(16).Vitamin A deficiency occurs in third world countries because of inadequate intake.In other countries it develops because of the fat malabsorption and liver disease.In addition, because of the effect on retinol binding protein,zinc deficiency may also cause vitamin A deficiency by affecting transportation and secretion from the liver of vitamin $A^{1,23}$. Symmetrical papules are seen as perifollicular in the skin and in the dorsal and lateral side of arms and legs ${ }^{1,23}$. Each papule central contains keratotic plug and often contains broken hair.These changes are called phrynoderma.Generalized xerosis is a common symptom of vitamin A deficiency. The most common early signs of eye is night blindness in vitamin A deficiency.Over time,xerophthalmia,Bitot's spots in conjunctiva and keratomalacia develop.Vitamin A is essential for skeletal system and bone development.Cranial nerve palsy and cerebral pseudotumor can be seen in vitamin A deficiency.Diagnosis is placed on clinical findings and decreased level of vitamin A in plasma ${ }^{1,23}$.

100000-300000 IU/ day dose of vitamin A are given in treatment.Visual changes are corrected within lesions respond to treatment is slower.

\section{VITAMIN A INTOXICATION}

Chronic intoxication can be seen in chidren using high doses of vitamin preperations and in adults who has tking $100000 \mathrm{IU} /$ day vitamin A for long-term.Xerosis and desquamation of the skin can be seen,the lips are dry and there are rhagades.Follicular keratosis and purpura may occur.In children cerebral pseudotumor and painful bone expansion may occur $^{28}$.Complaints are corrected with discontinuation of vitamin $A^{2}$.

\section{VITAMIN D DEFICIENCY}

Daily requirement of vitamin $D$ is around 400 IU.In vitamin D deficiency, in conjunction with muscular weakness in skeletal system,typically rickets and osteomalacia are seen. Typical skin changes are not observed in vitamin $D$ deficiency ${ }^{3,15}$.Vitamin $D$ synthesis occurs in the skin.Vitamin D syntesis is reduced with regular sun protection.Calcitriol recerptors are found in the epidermis and dermis.Therefore, vitamin D analoques are important in the treatment of psoriasis.

\section{VITAMIN E}

Most potent compounds of viatmin $E$ is alpha tocopherol Vitamin $E$ is estimated to have inhibitory effect on hyaluronidase,protective effect on the cell membranes from lipid peroxidation and contribute to vitamin A oxidation.Nowadays it is accepted to have biological antioxidant function.Anti-oxidant function of vitamin $E$ found in cell membrane is mainly based to inhibit lipid peroxidation. Vitamin $\mathrm{E}$ reduce diseases created by free radicals such as early aging,atherosclerosis, cancer, cataracts, neurop athy by its antioxidant effects ${ }^{29}$.

\section{VITAMIN K DEFICIENCY}

Vitamin $\mathrm{K}$ is essential cofactor for gamma carboxylation of the glutamic acid residues in the structure of clotting factors $2,7,9,10$, protein $C$ and S.Daily requirement of vitamin $K$ is near 1 ug7kg/day ${ }^{1,30}$.

Vitamin $\mathrm{K}$ deficiency leads to impairment of coagulation system. Often, bleeding in gastrointestinal, genitourinary, retroperitoneal regions is seen, and also skin ecchymosis, petechiae and purpura may occur ${ }^{1,18}$. Heart,skin, nose,oral mucusa,gastrointestinal and brain bleeding can be observed in infants. 
Table 3. Phisical signs of vitamin deficiencies.

\begin{tabular}{|c|c|}
\hline $\begin{array}{l}\text { VITAMIN } \\
\text { DEFICIEN } \\
\text { CIES }\end{array}$ & PHYSICAL SIGNS \\
\hline TIAMINE & $\begin{array}{lr}\text { *Symmetrical } & \text { progressive } \\
\text { polyneuritis,edema,fatique } & \\
\text { *Intestinal } & \text { obstruction,cardiac } \\
\text { insufficiency,glossitis } & \\
\text { *Korsakoff's psychosis and Wernicke's } \\
\text { encephalopathy }\end{array}$ \\
\hline $\begin{array}{l}\text { RIBOFLAV } \\
\text { IN }\end{array}$ & $\begin{array}{l}\text { *Perlesh, angular stomatitis,superficial fissures } \\
\text { *Glossitis,corneal vascularization } \\
\text { konjonctivit,intertsiel keratitis } \\
\text { * Seborrheic dermatitis-like erythematous scurfyy } \\
\text { lesions }\end{array}$ \\
\hline NIASIN & $\begin{array}{l}\text { *Erythematous macular lesions on sun exposed } \\
\text { areas } \\
\text { *Malar rush, sharply circumscribed, keratotic, } \\
\text { hyperpigmented plaques develop } \\
\text { *Keilosis,glossitis,angular stomatitis, painful fissure } \\
\text { and ulcerations on mucous membranes } \\
\text { *Diarrhea,anorexia,apathy, depression,pyschosis,c } \\
\text { oma,dementia encephalopathy }\end{array}$ \\
\hline PRIDOXIN & $\begin{array}{l}\text { *Seborrheic dermatitis-like lesions, keilosis,glossitis } \\
\text { *Erythema,hiperpigmentation on dorsal side of } \\
\text { arms and legs } \\
\text { *Peripheral } \\
\text { neuropathy,lymphopenia,allodynia, anemia } \\
\text { *Convulsions,anorexia,nausea,vomitting }\end{array}$ \\
\hline BIOTIN & $\begin{array}{l}\text { *Xerosis,generalized pallor,periorificial } \\
\text { dermatitis,alopecia } \\
{ }^{*} \text { Anorexia,irritability, depression,myalgia,hyperest } \\
\text { hesia,hypotonia }\end{array}$ \\
\hline $\begin{array}{l}\text { FOLIC } \\
\text { ACID }\end{array}$ & $\begin{array}{l}{ }^{*} \text { Anemia, diffuse hyperpigmentation,glossitis, } \\
\text { keilitis, apthous lesions in oral mucosa }\end{array}$ \\
\hline B12 & $\begin{array}{lll}\text { *Megaloblastic } & \text { anemia, } & \text { generalized } \\
\text { hyperpigmentation,glossitis, poliosis } & \\
\end{array}$ \\
\hline $\begin{array}{l}\text { VITAMIN } \\
\text { C }\end{array}$ & $\begin{array}{l}\text { *Follicular hyperkeratosis, perifollicular } \\
\text { hemorrhages,gingival hypertrophy, delayed wound } \\
\text { healing } \\
\text { *Edema,hyperplasia,spontaneous bleeding in the } \\
\text { gums } \\
\text { *Subungual,subcutaneous,intramuscular,intraartic } \\
\text { ular,subperiostal hemorrhages } \\
\text { *Fatique,weight loss,depression,edema } \\
\text { joints,artralgia,epistaxis,diarrhea }\end{array}$ \\
\hline $\begin{array}{l}\text { VITAMIN } \\
\text { A }\end{array}$ & $\begin{array}{l}\text { *Phrynoderma,generalized } \quad \text { kserosis,night } \\
\text { blindness,xerophthalmia ,bitot's spots in } \\
\text { conjunctiva,keratomalacia } \\
{ }^{*} \text { Cranial nerve palsy, pseudotumor cerebri }\end{array}$ \\
\hline $\begin{array}{l}\text { VITAMIN } \\
\text { K }\end{array}$ & $\begin{array}{l}\text { *Petechiae, purpura,ecchymosis on the skin } \\
\text { *Gastrointestinal,brain,nose,oral mucosa, } \\
\text { genitourinary, retroperitoneal bleeding }\end{array}$ \\
\hline $\begin{array}{l}\text { ESSENTIA } \\
\text { L FATTY } \\
\text { ACID }\end{array}$ & $\begin{array}{l}\text { *Alopecia, generalized kserosis,intertriginous } \\
\text { eruption } \\
\text { *Growth } \\
\text { hepatosteatosis,anemia,thrombocytopenia, } \\
\text { delayed wound healing }\end{array}$ \\
\hline
\end{tabular}

Vitamin $\mathrm{K}$ deficiency is frequent in patients with postoperative inadequate dietary intake and long-term broad-spectrum antibiotic use.This is because of the decrease of dietary intake and production from the intestine flora.In newborns, due to the lack of transition of fat-soluble vitamins from the placenta and because intestinal tract is sterile,vitamin $\mathrm{K}$ deficiency can be seen.

Deficiency may occur in cases leading to malabsorption such as regional enteritis,tropical sprue,cystic fibrosis, and biliary obstruction.Coumadin blocks convertion of vitamin $\mathrm{K}$ to epoxide,which is active form of vitamin $\mathrm{K}$, by inhibiting the vitamin $\mathrm{K}$ 2,3 epoxide reductase enzyme(1). High-dose salicylic acid inhibits vitamin $\mathrm{K}$ reductase. $\mathrm{N}$-methylthiotetrasole containing cephalosporins may inhibit carboxylase linked to vitamin K.(1) 5 to $10 \mathrm{mg} /$ day parenteral vitamin $\mathrm{K}$ is given as treatment. As synthesis of coagulation factors will return to normal for days after vitamin $\mathrm{K}$ treatment,fresh frozen plasma should be given in acute cases.

\section{ESSENTIAL FATTY ACID DEFICIENCY}

Essential fatty acids are non-saturated fatty acids, which can not be synthesized by the body.Essential fatty acids are linoleic acid and alpha linolenic acid.Arachidonic acid are synthesized from linoleic acid in the body. Essential fatty acids are essential in ensuring the normal epidermal barrier function.

Essential fatty acid deficiency is extremely rare.It may occur in low birth weight infants due to inadequate storage of fatty acids and infants with gastrointestinal abnormalities,and inflammatory bowel disease.In can be observed in those with gastrointestinal surgery, and in total parenteral nutrition intake that do not contain essential fatty acids in ${ }^{3,18}$. 
Alopecia,generalized xerosis, intertriginous eruption is seen.Growth retartadion, hepatosteatosis, anemia,thrombocytopenia, delayed wound healing and susceptibility to infections are other signs of essential fatty acid deficiency ${ }^{3,18}$.

In essential fatty acid deficiency,lineloic acid and arachidonic acid serum levels decrease.Eicosatrienoic acid levels are high.Eicosatrienoic acid/arachidonic acid ratio, which is normally 0.4 , increases. This is diagnostic for essential fatty acid deficiency. Treatment is provided with replacement of essential fatty acids.

\section{REFERENCES}

1. Miller SJ. Nutritional deficiency and the skin.J Am Acad Dermatol 1989:21;1-30.

2. Weismann K.Nutrition and the skin:In Rook $A$, Wilkinson D.S,Ebling F.J.G, Champion R.H,Burton J.L. $5^{\text {th }}$ ed. Oxfort: Blackwell Scientific Publications,1992:23:2358-81.

3. Sohi BP,McLaren DS,Sherertz EF. Cutaneous changes in nutritional disease:In: Dermatology in general medicine:Eds.Fitzpatrick TB,Eisen Az,Wolff K,Freedberg IM,Austen KF. $5^{\text {th }}$ ed.New York:Mc Graw Hill,Inc,1999:1725-37.

4. Albers SE,Brozena SJ,Fenske NA. A case of Kwashiorkor.Cutis 1993:51:445-6.

5. McLaren DS.Skin in protein energy malnutrition.Arch Dermatol 1987;123:1674-6.

6. Roe DA.Sulphur metabolism in relation to cutaneous disease.Br J Dermatol 1969;81(Suppl. 2):49-69.

7. Ganapathy S,Volpe SL.Zinc,Exercise and Thyroid Hormone Function.Critical Rewievs in Food Science and Nutrition 1999;39:369-90.

8. Neldner KH.Acrodermatitis Enteropathica and Other Zinc-Deficiency Disorders. In: Dermatology in general medicine:Eds.Fitzpatrick TB,Eisen Az,Wolff K,Freedberg IM,Austen KF. $5^{\text {th }}$ ed.New York:Mc Graw Hill,Inc,1999:1738-44.

9. Van Woume JP.Clinical and laboratory diagnosis of acrodermatitis enteropathica.Eur J Pediatr 1989;149:2.

10. Lee MG. Transient symptomatic zinc deficiency in a full term breast-fed infant.J Am Acad Dermatol 1990;23:375-9.

11. Buehring $L, G o l t z$ RW. Acquired zinc deficiency in a premature breast-fed infant. J Am Acad Dermatol 1993;28:499501.

12. Abitan $\mathrm{R}$, et al. Acquired zinc deficiency in a premature breast-fed infant (French). Ann Dermatol Venereol 1994;121:635.

13. Heinen $F$, et al. Zinc deficiency in an exclusively breast-fed preterm infant.Eur J Pediatr 1955;154:71-5.

14. Piela Z,Szuber M,Mach B,Janniger CK. Zinc deficiency in exclusively breast-fed preterm infant. Cutis 1998;61:197-200.
15. Arlette JP, Johnston MM.Zinc deficiency dermatitis in premature infants receiving prolonged parenteral alimentation. J Am Acad Dermatol 1981;5:37-42.

16. Bilen N. Deri hastalıklarında bazı vitamin,iz element ve esansiyel yağ asitlerinin rolü. T Klin Dermatol 1998;8:116-20.

17. Odom RB,James WD,Berger TG.Andrews' Disease of the skin.Clinical Dermatology. $9^{\text {th }}$ ed.Philadelphia:WB Saunders Co,2000:60615.

18. Tanaka K.New light on biotin deficiency.N Eng J Med 1981;304:839-40.

19. Mock DM,deLorimer AA,Liebman WM,Sweetman L,Baker H.Biotin deficiency: an unusual complication of parenteral alimentation: N Eng J Med 1981;304:817-20.

20. Nyhan WL. Inborn errors of biotin metabolism.Arch Dermatol 1987;123:1696-8.

21. Noppakun N, SwasdikulD.Reversible hyperpigmentation of skin and nails with white hair due to vitamin B 12 deficiency.Arch Dermatol 1986;122:896-9.

22. Marks VJ,Briggaman RA,Wheeler CE.Hyperpigmentation in megaloblastic anemia.J Am Acad Dermatol 1985;12;914-7.

23. Wallerstein RO.Scurvy.Semin Hematol 1976;13:2118

24. Pinnell SR,Murad SM,Darr D.Induction of collagen synthesis by ascorbic acid.Arch Dermatol 1987;123:1684-6.

25. Ghorbani AJ,Eichler C. Scurvy. J Am Acad Dermatol $1994 ; 30 ; 881-3$

26. Reuler JB,Broudy VC,Thomas CG.Adult Scurvy.JAMA 1985;253:805-7.

27. Yücecan S.Deri yaşlanmasında beslenmenin önemi.T Klin Kosmetol 1998;1:27-36.

28. Sharieff GQşHanten Karen.Pseudotumor cerebri and hypercalcemi resulting from vitamin A toxicity. Ann Emerg Med 1996;27:518-21.

29. Olsen RE. The function and metabolism of Vitamin K.Ann Rev Nutr 1984;4:281-337.

30. Ansell JE,Kumar R,Deykin D.The spectrum of vitamin K deficiency.JAMA 1977;238:40-2. 